\title{
Three multiplex snapshot assays for SNP genotyping in candidate innate immune genes
}

Lisa M Esteves $^{1}$, Sara M Bulhões ${ }^{1 \dagger}$, Maria J Brilhante ${ }^{1 \dagger}$ and Luisa Mota-Vieira ${ }^{1,2,3^{*}}$

\begin{abstract}
Background: Innate immune system is the first line of research when studying immune response to diverse infections and autoimmune/inflammatory diseases. This immune response has been reported to be genetically diverse, due to polymorphisms coded by different genes. For this reason, our purpose was to develop a multiplex assay that allows the genotyping of candidate single nucleotide polymorphisms (SNPs) in innate immune genes.

Findings: We developed three multiplex PCR panels coupled with the minisequencing (SNaPshot) technique (multiplex PCR, multiplex primer extension, and capillary electrophoresis). The panels were tested in a sample set composed of 100 anonymous DNAs from healthy blood donors living in São Miguel Island (Azores, Portugal). Sixteen relevant SNPs among nine genes of the innate immune system - IL1a, ILI $1 / L 6, I L 10, I L 12 R B 1, T L R 2, T L R 4$, $T L R 9$ and CD14 - were genotyped and validated by direct sequencing, with the exception of one that was undetected by minisequencing. We suggest that these panels can be used in future studies for detection of risk gene variants in several populations and/or diseases.

Conclusions: In summary, we propose a multiplex assay that is able to identify the most frequent candidate SNPs in innate immune genes, using a medium scale genotyping platform. The assays can be used to evaluate the risk gene variants in populations of various geographic origins.
\end{abstract}

Keywords: Innate immune genes, Polymorphisms, SNaPshot multiplex PCR

\section{Findings}

The innate immune system is involved in autoimmune/ inflammatory diseases, and is the first line of host defence against invading organisms. In part, most of these infective agents are successful in surviving, disseminating and infecting hosts, because of their ability to evade the innate immune system. Several studies suggested that, in human susceptibility to infection, host genetic makeup has a major role in innate immune response [1]. This susceptibility has been reported among infectious diseases such as tuberculosis [2], bacterial meningitis [3], leprosy $[4]$ and hepatitis $[5,6]$. The genetic variation of innate immune response to pathogens usually involves a variety of polymorphisms among different genes, including

\footnotetext{
* Correspondence: Imotavieira@hdes.pt

${ }^{\dagger}$ Equal contributors

'Molecular Genetics and Pathology Unit, Hospital of Divino Espírito Santo of Ponta Delgada, EPE, São Miguel Island, Azores, Portugal

${ }^{2}$ Instituto Gulbenkian de Ciência, Oeiras, Portugal

Full list of author information is available at the end of the article
}

those that encode toll-like receptors (TLRs) and interleukins (ILs).

The methods used to investigate genetic variation in $T L R$ s and $I L s$ are mostly singleplex PCR-based techniques, such as direct sequencing and real-time PCR. For small and medium-size laboratories, singleplex techniques became expensive and time-consuming when a large number of samples are evaluated. The alternatives to these methodologies, such as minisequencing assay - SNaPshot multiplex PCR -, have been successfully applied to support studies regarding oncogenic related genes [7-9], bacterial serotyping [10] and infectious diseases [11]. Moreover, the SNaPshot is a relatively simple and affordable method that allows more efficient and quick results when it is compared with singleplex techniques. In addition, it only requires the use of a thermal cycler and a capillary electrophoresis, which are equipments commonly available in molecular biology laboratories. In order to apply this technique to candidate genes studies associated with autoimmune and infectious diseases, we developed a multiplex assay designed to genotype 16 single nucleotide

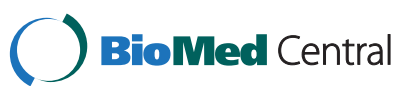

(c) 2013 Esteves et al.; licensee BioMed Central Ltd. This is an Open Access article distributed under the terms of the Creative Commons Attribution License (http://creativecommons.org/licenses/by/2.0), which permits unrestricted use, distribution, and reproduction in any medium, provided the original work is properly cited. 
polymorphisms (SNPs) among nine genes of the innate immune system: IL1 $\alpha, I L 1 \beta, I L 6, I L 10, I L 12 R B 1$, TLR2, TLR4, TLR9 and CD14.

\begin{abstract}
Methods
Selection of candidate innate immune system genes Candidate genes and SNPs were selected considering their association to human autoimmune and infectious diseases. For this purpose, we used an updated and publically downloadable database - the Human Genome Epidemiology (HuGE) Literature Finder (http:// www.hugenavigator.net) - that provides access to human genome epidemiology, including information on population prevalence of genetic variants, genedisease associations, gene-gene and gene-environment interactions, and evaluation of genetic tests [12].
\end{abstract}

\section{Population samples and sequence analysis}

The sample set was composed of DNA from 100 healthy blood donors living in São Miguel Island, obtained from the anonymized Azorean DNA bank located at the Hospital of Divino Espirito Santo of Ponta Delgada, EPE, of the same island [13]. This DNA bank was established after approval by the Ethics Committee for Health of the same Hospital, and follows the international ethical guidelines, which include informed consent, confidentiality, anonymity of personal data and abandonment option in case of expressed will.

From this sample set, 25 DNAs that evidence high SNP heterozygosity were selected to perform direct sequence analysis. Each $20 \mu \mathrm{l}$ PCR reaction contained $100 \mathrm{ng}$ of genomic DNA, $10 \mu \mathrm{M}$ primers, $100 \mu \mathrm{M}$ dNTPs (Promega), $25 \mathrm{nM} \mathrm{MgCl}$ (Qiagen), 1× Q-Solution (Qiagen), 1x buffer (Qiagen), $5 \mathrm{U}$ of HotStart Taq (Qiagen) and sterile water. The PCR started with an enzyme activation step at $94^{\circ} \mathrm{C}$ for $15 \mathrm{~min}$, then 40 cycles at $94^{\circ} \mathrm{C}$ for $1 \mathrm{~min}, 50^{\circ} \mathrm{C}$ for $1 \mathrm{~min}$ and $72^{\circ} \mathrm{C}$ for $1 \mathrm{~min}$, followed by a final extension step at $72^{\circ} \mathrm{C}$ for $7 \mathrm{~min}$. Amplification products were purified using the QIAquick PCR Purification Kit (Qiagen), according to the manufacturer's instructions. Purified products were sequenced, using the same primers of the PCR amplification, with the BigDye Terminator v1.1 cycle sequencing kit (Applied Biosystems) under the following conditions: $1 \mu \mathrm{l}$ ready reaction mix, $5 \mu \mathrm{l}$ BigDye sequencing buffer, 3.2 pmol forward or reverse primer, 7 ng DNA and sterile water to a final reaction volume of $20 \mu \mathrm{l}$. Cycle sequencing was performed using initial denaturation step at $96^{\circ} \mathrm{C}$ for $1 \mathrm{~min}$ followed by 25 cycles at $96^{\circ} \mathrm{C}$ for $10 \mathrm{~s}$, $50^{\circ} \mathrm{C}$ for $5 \mathrm{~s}$ and $60^{\circ} \mathrm{C}$ for $4 \mathrm{~min}$ in a GeneAmp ${ }^{\circledR}$ PCR System 2700 (Applied Biosystems). The sequencing products were purified with BigDye XTerminator ${ }^{\circledR}$ Purification Kit and separated by capillary electrophoresis in an automated sequencer (ABI 3130 Genetic Analizer, Applied Biosystems) with a $36 \mathrm{~cm}$ length capillary and POP- ${ }^{\mathrm{TM}}$ polymer, according to the manufacturer's instructions. Data were analyzed with Sequencing Analysis Software version 5.3.1 (Applied Biosystems). The alignment and edition of sequences were carried out using the Bioedit ${ }^{\mathrm{TM}}$ software version 7.0.0.

\section{Multiplex PCR primers and SNaPshot probes}

The first step of this study was to design a multiplex PCR assay that includes all 16 SNPs among the nine genes of the innate immune system (Table 1). The key point in this step is the combination of primer pairs in a master mix. We used the PrimerPlex biosoft software [14]. This software is automatically linked to the SNP database (dbSNP, www.ncbi.nlm.nih.gov/projects/SNP/) and only requests the insert of SNP rs number. Using this information, the program picks the DNA sequences from the dbSNP and mixture them. The output of the program gives the best multiplex primers and probes pairs with the less secondary structures possible (Tables 2 and 3). For this reason, it was not possible to use less PCR fragments to capture the SNPs: bigger fragments comprising more SNPs would allow the formation of more secondary structures. In the multiplex primer extension panels, poly- $\mathrm{T}$ tails of different lengths were added to each probe at their 5 ' ends, to separate extension products by size.

\section{Multiplex PCR amplification}

Multiplex PCRs were performed in $10 \mu \mathrm{l}$ total volume with Type-it ${ }^{\circledR}$ Mutation detect PCR kit (Qiagen) protocol. Thermal cycler conditions were: initial denaturation step at $95^{\circ} \mathrm{C}$ for $5 \mathrm{~min}$, then 35 cycles at $95^{\circ} \mathrm{C}$ for $30 \mathrm{~s}, 50^{\circ} \mathrm{C}$ (panel 1) or $51^{\circ} \mathrm{C}$ (panels 2 and 3) for $90 \mathrm{~s}$ and $72^{\circ} \mathrm{C}$ for $30 \mathrm{~s}$, followed by final extension at $68^{\circ} \mathrm{C}$ for $10 \mathrm{~min}$. PCR products were treated with a mix of $5 \mathrm{U}$ Exonuclease I (ExoI, Fermentas) and $1 \mathrm{U}$ of FastAP ${ }^{\mathrm{TM}}$ Thermosensitive Alkaline Phosphatase (SAP, Fermentas) at $37^{\circ} \mathrm{C}$ for $15 \mathrm{~min}$, and enzyme inactivation at $85^{\circ} \mathrm{C}$ for $15 \mathrm{~min}$. PCR quality was evaluated after electrophoresis in a $3 \%$ agarose gel.

\section{SNaPshot analysis}

SNaPshot analysis was performed using a SNaPshot Multiplex Kit protocol (Applied Biosystems). Products were treated with $1 \mathrm{U}$ of $S A P$ at $37^{\circ} \mathrm{C}$ for $60 \mathrm{~min}$ and $75^{\circ} \mathrm{C}$ for $15 \mathrm{~min}$, followed by a denaturation step at $95^{\circ} \mathrm{C}$ for $5 \mathrm{~min}$. Detection was carried out using $0.5 \mu \mathrm{l}$ of $\mathrm{SNaPshot}$ products mixed with $9 \mu \mathrm{l}$ of $\mathrm{HiDi}^{\mathrm{TM}}$ formamide and $0.5 \mu \mathrm{l}$ of GeneScan-120LIZ size standard (Applied Biosystems). Data were generated after capillary electrophoresis on an automated sequencer (ABI 3130 Genetic Analyzer, Applied Biosystems) with a $36 \mathrm{~cm}$ length capillary and POP- ${ }^{\mathrm{TM}}$ polymer and analyzed with GeneMapper analysis software version 3.7 (Applied Biosystems). 
Table 1 Genetic information of the 16 selected SNPs

\begin{tabular}{|c|c|c|c|c|c|}
\hline \multicolumn{3}{|l|}{ Gene } & \multicolumn{3}{|l|}{ SNP } \\
\hline Name & Symbol & NM & dbSNP & Position & Variation \\
\hline Interleukin 1 - alpha & ILIa & 000575.3 & rs1800587 & -889 & $C>T$ \\
\hline Interleukin 1 - beta & $I L T \beta$ & 000576.2 & rs16944 & -511 & $A>G$ \\
\hline \multirow[t]{2}{*}{ Interleukin 6} & IL6 & 000600.3 & rs1800797 & -596 & $A>G$ \\
\hline & & & rs1800795 & -174 & $C>G$ \\
\hline \multirow[t]{2}{*}{ Interleukin 10} & 1410 & 000572.2 & rs1800896 & -1082 & $A>G$ \\
\hline & & & rs1800872 & -592 & $A>C$ \\
\hline \multirow[t]{2}{*}{ Interleukin 12 receptor, beta 1} & $\mid L 12 R B 1$ & 005535.1 & rs11575934 & +705 & $A>G$ \\
\hline & & & rs401502 & +1196 & $C>G$ \\
\hline \multirow[t]{3}{*}{ Toll-like receptor 2} & TLR2 & 003264.3 & rs4696480 & -16933 & $A>T$ \\
\hline & & & rs121917864 & +2029 & $C>T$ \\
\hline & & & rs5743708 & +2259 & $A>G$ \\
\hline \multirow[t]{2}{*}{ Toll-like receptor 4} & TLR4 & 138554.3 & rs4986790 & +896 & $A>G$ \\
\hline & & & rs4986791 & +1196 & $C>T$ \\
\hline Toll-like receptor 9 & TLR9 & 017442.3 & rs187084 & -1486 & $C>T$ \\
\hline \multirow[t]{2}{*}{ Cluster of differentiation 14} & CD14 & 000591.3 & rs2569190 & -260 & $A>G$ \\
\hline & & & rs2569191 & -159 & $C>T$ \\
\hline
\end{tabular}

Table 2 Primer sequences used for multiplex PCR amplification panels

\begin{tabular}{|c|c|c|c|c|c|}
\hline Gene & $\begin{array}{l}\text { SNP } \\
\text { (rs) }\end{array}$ & $\begin{array}{l}\text { Forward } \\
\left(5^{\prime} \rightarrow 3^{\prime}\right)\end{array}$ & $\begin{array}{l}\text { Reverse } \\
\left(5^{\prime} \rightarrow 3^{\prime}\right)\end{array}$ & $\begin{array}{l}\text { Amplicon } \\
\text { size (bp) }\end{array}$ & $\begin{array}{l}\text { PCR } \\
\operatorname{mix} \\
(\mu \mathrm{M}) \\
\end{array}$ \\
\hline \multicolumn{6}{|c|}{ Panel 1} \\
\hline ILT-a & 1800587 & GCAATAGACCTTATGACACCTAAC & GGTAGAGAAGAGAACAGTGGTATT & 731 & 3.0 \\
\hline ILI- $\beta$ & 16944 & AGTATATGTGGGACAAAGTGGAAG & CTCATCTGGCATTGATCTGGTT & 389 & 1.4 \\
\hline IL6 & 1800795 & AGCCTGTTAATCTGGTCACTGA & CTTGTGGAGAAGGAGTTCATAGC & 498 & 3.2 \\
\hline IL10 & 1800872 & TTCTATGTGCTGGAGATGGTGTA & GGGTGGGCTAAATATCCTCAAAG & 385 & 1.4 \\
\hline IL12 & 11575934 & GGTTAAGTGACTGGTGCCAAG & TCCTGTACTCAGAGTGATCTTACC & 210 & 3.0 \\
\hline \multicolumn{6}{|c|}{ Panel 2} \\
\hline$T L R 2$ & 5743708 & TGCTGCCATTCTCATTCTTCCTG & TCCTCAAATGACGGTACATCCA & 282 & 1.4 \\
\hline IL10 & 1800896 & ATCTGAAGAAGTCCTGATGTCACT & ACCATCTCCAGCACATAGAATGA & 367 & 1.4 \\
\hline$T L R 2$ & 4696480 & CATAGTTGTCACAGTCCCTTGG & TGGCATGATCTCGGCTCAC & 346 & 4.0 \\
\hline IL6 & 1800797 & GGTGAAGAGACTCAGTGGCAAT & AGTGACCAGATTAACAGGCTAGAAT & 444 & 2.0 \\
\hline TLR4 & 4986791 & CCGATTAGCATACTTAGACTACTACCT & AGACTGGACAAGCCATTGAAGAT & 555 & 3.2 \\
\hline \multicolumn{6}{|c|}{ Panel 3} \\
\hline $1 L 12$ & 401502 & ACCTCTGTATGACATTGAGTAAGC & GAACCAACGGGACCACCAT & 285 & 1.0 \\
\hline$T L R 2$ & 121917864 & CTGTGCTCTGTTCCTGCTGAT & GAAATGGGAGAAGTCCAGTTCATAC & 382 & 1.0 \\
\hline$T L R 9$ & 187084 & ATTCATTCATTCAGCCTTCACTCAG & CCATCCAGCCTTCTTACAAACCT & 324 & 1.0 \\
\hline CD14 & 2569190 & GGCTTCCAGGCTTCACACT & AGGACACTGCCAGGAGACA & 236 & 1.0 \\
\hline TLR4 & 4986790 & TCCCTGAACCCTATGAACTITATCC & AGGCTTGGTAGATCAACTTCTGAA & 494 & 1.0 \\
\hline CD14 & 2569191 & AAGGAAGGGATGGGACTATGTT & CAGGAATCTGAGGCAAGAGAAT & 347 & 1.0 \\
\hline
\end{tabular}


Table 3 Extension probes used for multiplex primer extension

\begin{tabular}{|c|c|c|c|c|c|}
\hline Gene & Positionchange & Variation & $\begin{array}{l}\text { Extension probe } \\
\left(5^{\prime} \rightarrow 3^{\prime}\right)\end{array}$ & $\begin{array}{l}\text { Probe } \\
\text { size } \\
\text { (bp) }\end{array}$ & $\begin{array}{l}\text { PCR } \\
\operatorname{mix} \\
(\mu \mathrm{M}) \\
\end{array}$ \\
\hline \multicolumn{6}{|c|}{ Panel 1} \\
\hline IL1-a & -889 & $C>T$ & TTAATAATAGTAACCAGGCAACA & 23 & 2.0 \\
\hline IL1- $\beta$ & -511 & $A>G$ & TIIIIIIITGGTGCTGTTCTCTGCCTC & 28 & 1.2 \\
\hline IL6 & -174 & $C>G$ & TITIIITIIITITCCCCTAGTTGTGTCTTGC & 33 & 2.0 \\
\hline IL10 & -592 & $A>C$ & TाTाTाTाTाTाTाTाTाTCCTGTGACCCCGCCTGT & 38 & 1.2 \\
\hline $1 L 12$ & +705 & $A>G$ & 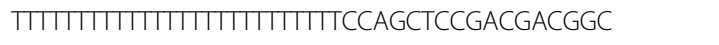 & 43 & 2.0 \\
\hline \multicolumn{6}{|c|}{ Panel 2} \\
\hline TLR2 & +2259 & $A>G$ & TITITIGCGCTTCTGCAAGCTGC & 24 & 0.8 \\
\hline IL10 & -1082 & $A>G$ & TIIIITCACTACTAAGGCTTCTITGGGA & 30 & 0.8 \\
\hline TLR2 & -16933 & $A>T$ & TIITIIITITITIITATTGAAGGGCTGCATCTGG & 36 & 3.2 \\
\hline IL6 & -596 & $A>G$ & TTTTITTITTITITITITGTAACTGCACGAAATTGAGG & 42 & 0.8 \\
\hline TLR4 & +1196 & $C>T$ & 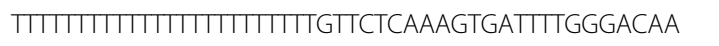 & 48 & 3.2 \\
\hline \multicolumn{6}{|c|}{ Panel 3} \\
\hline $1 L 12$ & +1196 & $C>G$ & TITCAGGTGGCAAGGCCCC & 20 & 1.0 \\
\hline TLR2 & +2029 & $C>T$ & TITTCCCTTCAAGTTGTGTCTTCATAAGC & 30 & 1.4 \\
\hline TLR9 & -1486 & $C>T$ & TITTITITITTCAGATAAAAGATCACTGCCCT & 35 & 1.0 \\
\hline CD14 & -260 & $A>G$ & TाTाIIITाIIIIITाTGGATGTITCAGGGAGGGGGG & 40 & 1.0 \\
\hline TLR4 & +896 & $A>G$ & TIIIITITITITIITTAGCATACTTAGACTACTACCTCGATG & 45 & 1.0 \\
\hline CD14 & -159 & $C>T$ & 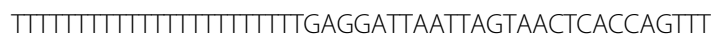 & 50 & 2.0 \\
\hline
\end{tabular}

\section{Results and discussion}

The strategy of the present work included the design of a multiplex assay, in order to detect 16 SNPs among nine genes of the innate immune system. For all panels, the specificity of each amplicon was evaluated first in singleplex and after in multiplex PCR, followed by electrophoresis in an agarose gel. According to the amplicons quality, primer concentrations and annealing temperatures were adjusted in order to obtain bands with equal intensities (Table 2). SNPs detection also implicated the optimisation of the three multiplex primer extension (SNaPshot) panels. In order to achieve more comparable peak heights, we adjusted probe concentrations (Table 3).

Figure 1 represents the electropherograms obtained for each panel. Polymorphisms were identified on the basis of peak size and colour. As expected, minor shifts in the electrophoretic mobility were observed due to the incorporated base at the end of each probe and to the POP $-7^{\mathrm{TM}}$ polymer. However, these shifts did not interfered with the analysis because poly- $T$ tails increased probes spacing. Some samples evidenced one PCR product peak with more than one colour due to pull-ups, as illustrated in Figure 1A, IL1- $\beta$ polymorphism $-511 \mathrm{~A}>\mathrm{G}$. The peak in blue produced a secondary peak in black or green. This problem is probably due to a bleed-through when an adjacent lane has very high peak heights. Nevertheless, it was resolved by reducing the concentration of the respective probe.

The panels, here described, were evaluated in 100 DNA samples. From the 16 SNPs, we expected to identify 32 alleles and 48 different genotypes. However, we did not identify the $G$ allele of the IL12 c.705 A>G (the last SNP in panel 1) and its inherent genotypes (AG and GG). This missing allele is a failure of the minisequencing reaction, since the Sanger DNA sequencing (validation test) revealed the presence of the two genotypes in our sample (Figures 2A and 2B). Indeed, in a study carried out in the Brazilian population, the multiplex protocol, which was optimized for simultaneous detection of 12 autosomal SNPs, revealed that large amplicons (413 and $576 \mathrm{bp}$ ) had lower sensitivity to allele detection in multiplex minisequencing [15]. Moreover, two homozygous genotypes were not observed in TLR2, namely: AA for c. $2259 \mathrm{~A}>\mathrm{G}$, and TT for c.2029C $>\mathrm{T}$ (panel 2 and 3, respectively). According to the SNP database (dbSNP), these genotypes were not found in the 11 HapMap populations (phase 3), which includes the Europeans (CEU). In fact, the A allele (c.2259A $>$ G) is rare - 0.052 in CEU - and was only detected in homozygosity in tuberculosis patients [16]; the $\mathrm{T}$ allele $(\mathrm{c} .2029 \mathrm{C}>\mathrm{T})$ is observed in Asian and African populations, but it seems 


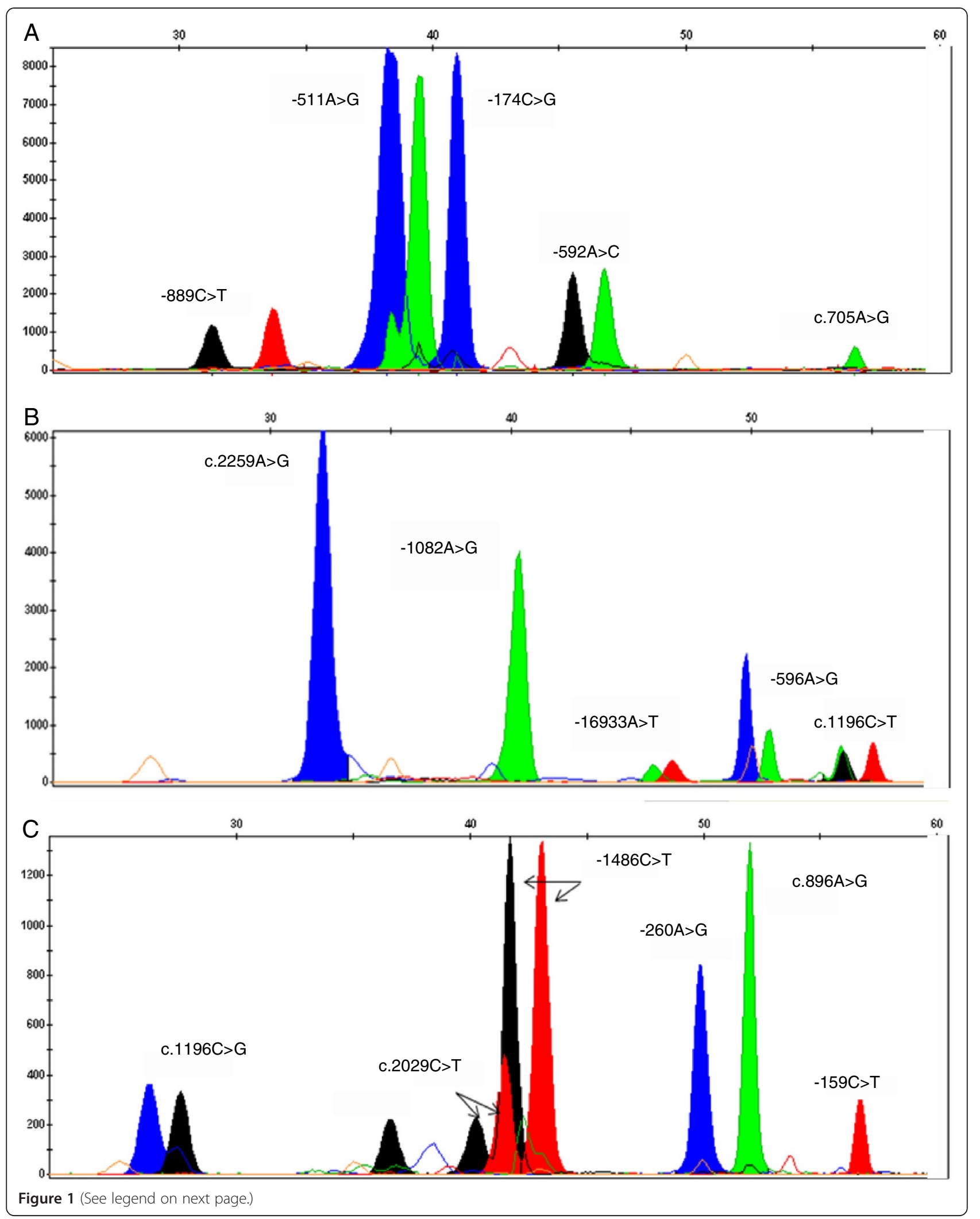


(See figure on previous page.)

Figure 1 Electropherograms obtained for the three multiplex primer extension panels. Capillary electrophoresis of SNaPshot products was

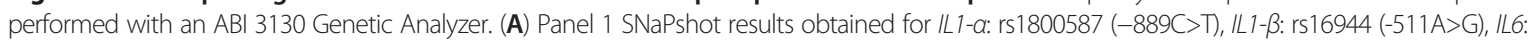
rs1800795 (-174C>G), IL10: rs1800872 (-592A>C) and IL12: rs11575934 (c.705A>G). (B) Panel 2 SNaPshot results for TLR2: rs5743708 (c.2259A>G), IL10: rs1800896 (-1082A>G), TLR2: rs4696480 (-16933A>T), IL6: rs 1800797 (-596A>G) and TLR4: rs4986791 (c.1196C > T). (C) Panel 3 SNaPshot results for IL12: rs401502 (c.1196C>G), TLR2: rs121917864 (c.2029C> T), TLR9: rs187084 (-1486C> T), CD14: rs2569190 (-260A>G), TLR4: rs4986790 (c.896A>G) and CD14: rs2569191 ( $-159 \mathrm{C}>\mathrm{T})$. Nucleotides are represented by the following colours: $\mathrm{A}=$ green; $\mathrm{C}=$ black; $\mathrm{G}=$ blue; $\mathrm{T}=$ red.

to be absent in white populations $[17,18]$. Nevertheless, in the present work, the $\mathrm{T}$ allele was identified in heterozygosity in one individual, as illustrated in Figure 1C (c.2029C $>\mathrm{T})$ and was confirmed by sequencing (Figure 2C). This finding is not surprising since our previous studies show African influence in São Miguel population [19,20].

In order to validate our assays, we selected 25 DNA samples for Sanger DNA sequencing. The results confirmed the 44 genotypes previously obtained by multiplex primer extension assay, as well as the two corresponding genotypes (AG and $\mathrm{GG}$ ) of the missing allele IL12 c.705G.

Considering that these nine candidate innate immune genes have been investigated in autoimmune and infectious diseases through association studies, the three panels here described may allow the detection of at least
15 risk gene variants in all populations. Panel 1, for example, contains 4 SNPs in interleukin genes, which are often related to autoinflammatory diseases [21]. On the other hand, panel 2 and 3 could be used for polymorphism genotyping (5 and 6 SNPs, respectively) in studies of infectious diseases associated with microbial pathogens, whose recognition by the innate immune system depends on Toll-like receptors [22].

\section{Conclusions}

With this study, we were able to develop combined multiplex PCR amplifications and SNaPshot reactions that genotypes 15 SNPs among nine innate immune response genes. These multiplex panels can be useful to investigate candidate immune response genes, using a medium scale genotyping platform, rather than singleplex PCR-based techniques.

A

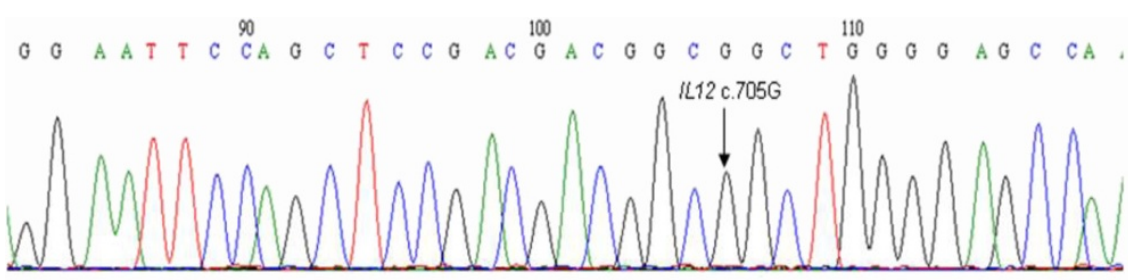

B
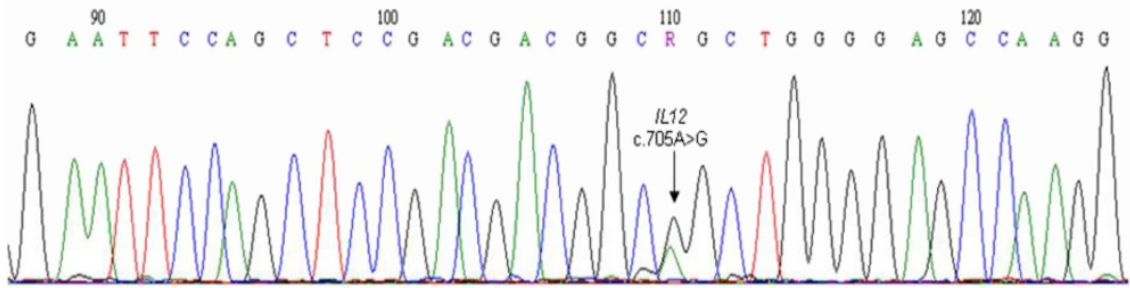

C

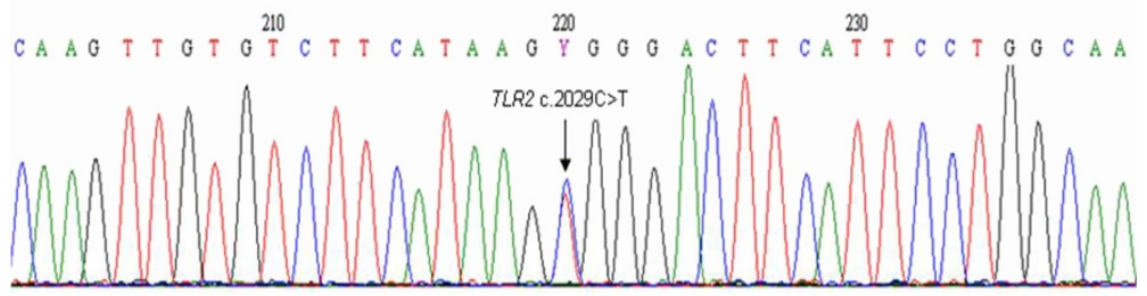

Figure 2 Electropherograms obtained from Sanger DNA sequencing. (A) and (B) corresponds to the DNA sequence flanking $/ L 12$ gene at c.705A $>$ G, being the genotypes indicated by the arrow - GG and AG - respectively. (C) Corresponds to the DNA sequence flanking TLR2 at c.2029C>T. The arrow indicates the genotype CT. 


\section{Competing interests}

The authors declare that they have no competing interests.

\section{Authors' contributions}

LME developed and performed the multiplex experiments and drafted the manuscript. SMB and MJB did the validation assays by Sanger DNA sequencing. LMV provided scientific orientation and revised the manuscript All authors read and approved the final manuscript.

\section{Acknowledgments}

This work was supported the "Fundação Calouste Gulbenkian" (grant reference number P-99888: SDH49), and "Direcção Regional da Ciência, Tecnologia e Comunicações (DRCTC)" of Azores Government. The authors wish to thank Drs Claudia Castelo Branco and Renato Pires for useful comments on the article.

\section{Author details}

${ }^{1}$ Molecular Genetics and Pathology Unit, Hospital of Divino Espírito Santo of Ponta Delgada, EPE, São Miguel Island, Azores, Portugal. ${ }^{2}$ Instituto Gulbenkian de Ciência, Oeiras, Portugal. ${ }^{3}$ Center for Biodiversity, Functional \& Integrative Genomics (BIOFIG), Lisbon, Portugal.

Received: 19 July 2012 Accepted: 11 January 2013

Published: 7 February 2013

\section{References}

1. Hill AV: Evolution, revolution and heresy in the genetics of infectious disease susceptibility. Philos Trans R Soc Lond B Biol Sci 2012, 367:840-849.

2. Tobin DM, Vary JC Jr, Ray JP, Walsh GS, Dunstan SJ, Bang ND, Hagge DA, Khadge S, King MC, Hawn TR, et al: The Ita4h locus modulates susceptibility to mycobacterial infection in zebrafish and humans. Cell 2010, 140:717-730

3. van Well GTJ, Sanders MS, Ouburg S, van Furth AM, Morre SA: Polymorphisms in Toll-Like Receptors 2, 4, and 9 are highly associated with hearing loss in survivors of bacterial meningitis. PLOS One 2012, 7:e35837.

4. Mira MT, Alcaïs A, Nguyen VT, Moraes MO, Di Flumeri C, Vu HT, Mai CP, Nguyen $T H$, Nguyen NB, Pham XK, et al: Susceptibility to leprosy is associated with PARK2 and PACRG. Nature 2004, 427:636-640.

5. Mbarek H, Ochi H, Urabe Y, Kumar V, Kubo M, Hosono N, Takahashi A, Kamatani $Y$, Miki D, Abe H, et al: A genome-wide association study of chronic hepatitis B identified novel risk locus in a Japanese population. Hum Mol Genet 2011, 20:3884-3892.

6. Thomas DL, Thio CL, Martin MP, Qi Y, Ge D, O'Huigin C, Kidd J, Kidd K, Khakoo SI, Alexander G, et al: Genetic variation in IL28B and spontaneous clearance of hepatitis C virus. Nature 2009, 461:U752-U798.

7. Hurst CD, Zuiverloon TC, Hafner C, Zwarthoff EC, Knowles MA: A SNaPshot assay for the rapid and simple detection of four common hotspot codon mutations in the PIK3CA gene. BMC Res Notes 2009, 2:66.

8. Lurkin I, Stoehr R, Hurst CD, van Tilborg AAG, Knowles MA, et al: Two Multiplex Assays that simultaneously identify 22 possible mutation sites in the KRAS, BRAF, NRAS and PIK3CA genes. PLOS One 2010, 5:e8802.

9. Filippini S, Blanco A, Fernandez-Marmiesse A, Alvarez-Iglesias V, Ruiz-Ponte C, Carracedo A, Vega A: Multiplex SNaPshot for detection of BRCA1/2 common mutations in Spanish and Spanish related breast/ovarian cancer families. BMC Med Genet 2007, 8:40.

10. Ben-Darif E, Jury F, De Pinna E, Threlfall EJ, Bolton FJ, Fox AJ, Upton M: Development of a multiplex primer extension assay for rapid detection of Salmonella isolates of diverse serotypes. J Clin Microbiol 2010, 48:1055-1060

11. Bouakaze C, Keyser C, de Martino SJ, Sougakoff W, Veziris N, Dabernat H, Ludes B: Identification and genotyping of Mycobacterium tuberculosis complex species by use of a SNaPshot minisequencing-based assay. J Clin Microbiol 2010, 48:1758-1766.

12. Yu W, Gwinn M, Clyne M, Yesupriya A, Khoury MJ: A Navigator for Human Genome Epidemiology. Nat Genet 2008, 40(2):124-5.

13. Mota-Vieira L, Pacheco PR, Almeida ML, Cabral R, Carvalho J, Branco CC, de Fez L, Peixoto BR, Araújo AL, Mendonça P: Human DNA bank in São Miguel island (Azores), a resource for genetic diversity studies. In Progress in Forensic Genetics, Proceedings of the 21st International Congress of Forensic
Genetics, 13 - 17 September Ponta Delgada, Volume 1288. Edited by Amorim A, Côrte-Real F, Morling N.; 2005:388-390.

14. PREMIER Biosoft software. http://www.premierbiosoft.com/primerplex/index. html.

15. Carvalho CM, Pena SD: Optimization of a multiplex minisequencing protocol for population studies and medical genetics. Genet Mol Res 2005, 4:115-125

16. Ogus AC, Yoldas B, Ozdemir T, Uguz A, Olcen S, Keser I, Coskun M, Cilli A, Yegin O: The Arg753GIn polymorphism of the human toll-like receptor 2 gene in tuberculosis disease. Eur Respir J 2004, 23:219-223.

17. Ioana M, Ferwerda B, Plantinga TS, Stappers M, Oosting M, McCall M, Cimpoeru A, Burada F, Panduru N, Sauerwein R, et al: Different patterns of Toll-like receptor 2 polymorphisms in populations of various ethnic and geographic origins. Infect Immun 2012, 80:1917-1922.

18. Thurow HS, Sarturi CR, Fallavena PR, Paludo FJ, Picanço JB, Fraga LR, Graebin P, de Souza VC, Dias FS, Nóbrega Ode T, et al: Very low frequencies of Toll-like receptor 2 supposed-2029T and 2258A (RS5743708) mutant alleles in southern Brazilian critically ill patients: would it be a lack of worldwide-accepted clinical applications of Toll-like receptor 2 variants? Genet Test Mol Biomarkers 2010, 14:405-419.

19. Pacheco PR, Branco CC, Cabral R, Costa S, Araújo AL, Peixoto BR, Mendonça $P$, Mota-Vieira L: The Y-chromosomal heritage of the Azores Islands population. Ann Hum Genet 2005, 69:145-156.

20. Pacheco PR, Branco CC, Gomes CT, Cabral R, Mota-Vieira L: HLA Class I and Il profiles in São Miguel Island (Azores): genetic diversity and linkage disequilibrium. BMC Res Notes 2010, 3:134.

21. Zenewicz LA, Abraham C, Flavell RA, Cho JH: Unravelling the genetics of autoimmunity. Cell 2010, 140:791-797.

22. Fang J, Fang D, Silver PB, Wen F, Li B, Ren X, Lin Q, Caspi RR, Su SB: The Role of $T L R 2, T R L 3, T R L 4$, and TRL9 signalling in the pathogenesis of autoimmune disease in a retinal autoimmunity model. Invest Ophthalmol Vis Sci 2010, 51:3092-3099.

\section{doi:10.1186/1756-0500-6-54}

Cite this article as: Esteves et al.: Three multiplex snapshot assays for SNP genotyping in candidate innate immune genes. BMC Research Notes $20136: 54$.

\section{Submit your next manuscript to BioMed Central and take full advantage of:}

- Convenient online submission

- Thorough peer review

- No space constraints or color figure charges

- Immediate publication on acceptance

- Inclusion in PubMed, CAS, Scopus and Google Scholar

- Research which is freely available for redistribution 